\title{
Promotion Mix and the Role of Tourism Activist Groups on the Rate of Tourist Visits to Benan Island, Riau Islands Province, Indonesia
}

\author{
Lia Suprihartini ${ }^{1}$, Firmansyah Kusasi ${ }^{2}$, Akhirman $^{3}$ \\ \{lia.arai@gmail.com ${ }^{1}$, fkusasi@umrah.ac.id ${ }^{2}$, akhirman@gmail.com $\left.{ }^{3}\right\}$ \\ ${ }^{1,2,3}$ Raja Ali Haji Maritime University
}

\begin{abstract}
Benan Island is a marine tourism destination in the Riau Islands Province. The local government has carried out tourism promotion through the relevant agencies. However, the level of tourist visits to Benan Island is still fluctuating. Lack of access to information, either through conventional promotional activities or based on digital data, is deemed not to have a strong influence in maintaining the stability of the level of tourist visits. Thus, the solutions are increasing tourism promotion activities (promotion mix) and the role of tourism awareness groups and looking for alternative promotion mixmodels that effectively increase the tourist visit rate.This study suggests that the promotion mix and tourism activist group significantly affect visits to Benan Island partially or simultaneously. Furthermore, the tourism activist group acts as a mediating variable somewhat(instead ofwholly) of the indirect relationship between the promotion mix and the rate of tourist visits. The local government did not optimally utilize the promotion mix and the tourism activist group to promote the number of visits to Benan Island.
\end{abstract}

Keywords: promotion mix, tourism activist groups, tourist visit rate

\section{Introduction}

\subsection{Research Background}

Benan Island has the potential to excel inmarine tourism and improve the welfare of the local people. Although there was a high level of tourist arrivals in the Riau Islands Province, more than 2.6 million in 2019, the number of tourist visits to Benan Island was low. According to the Department of Tourism, Youth and Sports (Disparpora) of Lingga Regency year 2018, tourists who visited Benan Island only originated from a few countries. The tourist's origin visiting Benan Island is only in a matter of several countries.

Promotional activities have been carried out by related parties, namely the Lingga Regency Government. However, these activities are not considered to significantly influence the level of tourist visits to Benan Island in particular. Various events have also been carried out to increase tourist visits, including the annual Fishing Festival and Tour De Benan.The promotional activities that have been carried out needto be evaluatedto establish whether they effectively achieve the goals desired by all parties for the development of marine tourism on Benan Island, Lingga Regency.

The existence of tourism activist groups, known as POKDARWIS (Kelompok Sadar Wisata-Tourism Awareness Group), has a major role in tourism objects in an area. Ongoing 
training and guidance by related parties arenecessary for optimizing the ability of Pokdarwis in carrying out their roles.

The high numberof tourist visits toseveral other areas in the Archipelago Province hasnot been accompanied by an increase in tourist visits in Lingga Regency, especially Benan Island. Promotional activities that have been carried out have not increased the number of tourist visits to the area. By identifying the promotion mix that has been carried out, it is hoped that the right promotion mix model for the development of marine tourism in Benan Island can be found.The increasing role of Pokdarwis on Benan Islandis also expected to have a more significantinfluence on increasing the number of tourists.

\subsection{Research Purposes}

The objectives of this research, "Promotion Mix and the Role of Tourism Activist Groups on the Rate of Tourist Visits in Benan Island."are twofold. Firstly, to determine the influence of the promotion mix and tourism activist groups on the rate of tourist visits in Benan Islandand secondly, to determine whether the tourism activist groups are the mediating variable of the indirect effect between promotion mix and tourist visits rate. Based on the problem formulationdescribed previously, this study then aims to analyze the implications of promotion mix and Tourism activist groups on the rate of Tourist Visits to Benan Island, in Lingga Regency, Kepulauan Riau Province.

\subsection{Literature Review}

In every marketing activity, be it product or service marketing, the promotion mix has a significant role in success. The right form of promotion can increase sales of both products and services.At the same time, the wrong form of promotional activities will certainly waste fundsand not achieve the goals and objectives desired by producers (Mursid, 2013).

The promotion mix consists of five main tools, namely: a)Advertising: non-personal presentation, promotion of ideas, promotion of products or services by certain sponsors who are paid; b) Sales Promotion: various short-term incentives to encourage the desire to try or buy a product or service; c) Public relations and publicity: various programs to promote and protect the image of the company or its products; d) Personal Selling:

Direct interaction with prospective buyers to make a presentation, answer directly and receive orders; and e) Direct marketing: the use of mail, telephone, facsimile, e-mail and other non-personal contact tools to communicate directly with or obtain direct responses from certain customers and potential customers(Kotler \& Amstorong, 2016).

The Tourism Activist Group or Tourist Awareness Group (Pokdarwis) is a tourism driving group formed by community members, especially those concerned about developing tourism in their area. Pokdarwis is one of the elements of stakeholders in the community that has a connection to and an important role in developing and realizing Sadar Wisataand Sapta Pesona, a government program on tourism.To increase the active role and efficiency of the local community in tourism development, it needs various empowerment efforts. The positive benefits ofthe development activities will improve the welfare of the community. ${ }^{1}$

This promotion mix and the tourism activist groups such as Pokdarwis are responsible for increasing tourist visits to an area. The right selection of marketing media and promotion

${ }^{1}$ Source: Ministry of Tourism and Creative Economy, (2012). 
mix is one of the most influential aspects in the success of tourism development. Additionally,through personal communication, community members can generate interest in tourist destinations and encourage tourists to visit Benan Island.

Previous research by Rispawati(2019),Setiawan \& Farid (2014), and Handayani \& Dedi (2017) are among others to find that promotion mix that includes word of mouth, public relations, personal selling, events, exhibitions, merchandise, publications, websites. The quality of service isimportantin increasing the number of tourist visits.

\subsection{Research Framework}

The research framework ofthis study describes the influence of tourism activist groups and promotion mix on the rate of tourist visits with tourism activist groups as a mediating variable. Based on literature review and previous research, the research framework can be seen below as shown in Fig.1.

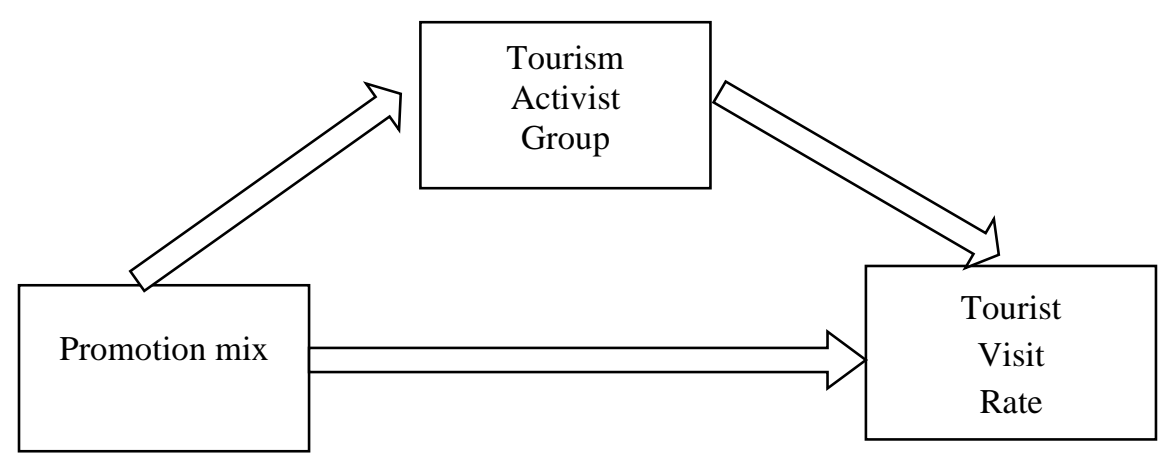

Fig.1. Research Framework

\section{Research Methods}

\subsection{Research Design}

This research uses primary datacollected through a survey of 100 respondents, according to Sujarweni (2015), assuming the population members arehomogeneous. The sampling technique ispurposive accidental sampling with the criteriaof being a resident of Benan Island aged between 15-64 years old.This research was conducted on BenanIslandin September 2020.

\subsection{Analysis Method}

This study appliesthe Partial Least Square (PLS) approach on the Warp PLS platformversion 3.0. The advantage of WarpPLS compared to other SEM-PLS models is that it can identify nonlinear relationships between latent variablesand correct path coefficient values. Since most relationships between variables are nonlinear, WarpPLS can find a real relationship between latent variables. 


\subsection{Steps of the PLS-SEM Analysis}

To test the hypotheses,the PLS-SEM analysis carried out in this research follows the three-step processsuggested by Latan \& Ghozali(2012):
a. Model Conceptualization
b. Determine the algorithm and the resampling method
c. Draw a path diagramand evaluationmodel

\subsubsection{Model Conceptualization}

From our discussion above, a concept model of the research is proposed, as shown in Fig.2 below. The model depicts the relationship between variables in the study.

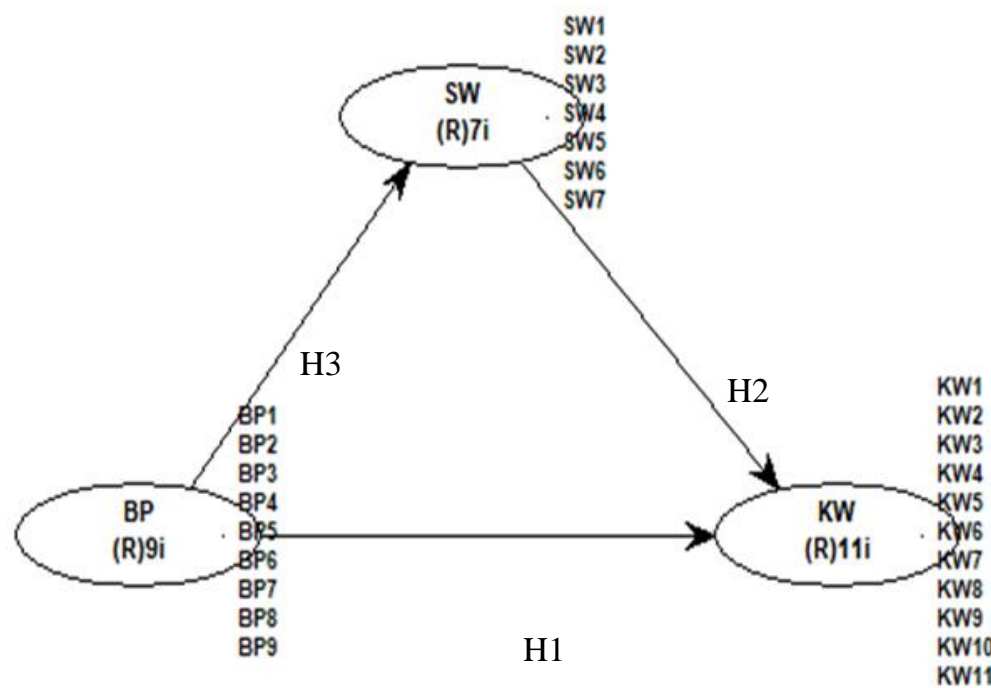

Fig.2. The Model of Relationships Between Constructs

The hypotheses of the research are:

H1: It is suspected that the Promotion Mix affects the Tourist Visit Rate.

H2: It is suspected that the Tourism Activist Group affects the Tourist Visit Rate.

H3: It is suspected that the Tourist Activist Group is the mediating variable between the Promotion Mix and Tourist Visit Rate.

Key to notations:

BP - latent variable of Promotion Mix

SW - latent variable of Tourism Activist Group

KW - dependent latent variable Tourist Visit Rate.

\subsubsection{Algorithm Settings and Resampling Method}

This research sets the Warp3 PLS Regression algorithmto identify whether the best relationship between latent variables is linear, quadratic, or following the $S$ curve pattern (cubic function).We used the blindfolding resampling algorithm for resampling, considering 
thatthis method is a moderate form between jackknifing and bootstrapping. The number of samplesis 100 cases, and the number of resamplingis determined at 100 . This study is based on the assumption that indicators are reflective, i.e. not formative. The indicators are the consequence of constructs, wherethe constructs are properties that describe indicators, and indicators can be interchanged equally. For analysis, this study selectsthe ranked data analysis type, where all data is automatically ranked before SEM analysis (i.e. original data is stored in an unrated format). This methodeffectively eliminatesoutliers. The range of values as an outlier feature is significantly reducedwithout any reduction in sample size. Itis suitable for data with an ordinal scale to measure perception, such as the Likert scale.

\section{$3 \quad$ Results and Discussion}

\subsection{Convergent Validity Analysis}

Testing the convergent validity of the measurement instrument (questionnaire)is part of the measurement model, which in SEM-PLS is usually referred to as the outer model. At the same time, in covariance-based SEM, it is called confirmatory factor analysis (CFA). There are two criteria for reflective constructs to assess whether the outer model meets the requirements of convergent validity: a). loading must be above 0.70 , and b). significant pvalue $(<0.05)$ (Sholihin \& Ratmono, 2013). When these conditions are met, the measurement of the SPM construct has fulfilled the requirements of convergent validity. In addition, it is expected that loading to other constructs (cross-loadings) is of lower value than to that construct.

In some cases, loading requirements above 0.70 are often not met, especially for newly developed questionnaires. Therefore, loading between 0.40-0.70 should be considered to be maintained. Indicators with loading below 0.40 should be removed from the model. Unless, for indicators with loadings between 0.40 and 0.70 , we should analyze the decision's impacton deleting these indicators on average variance extracted (AVE) and composite reliability. We can remove the indicator with a loading between 0.40 and 0.70 if the indicator may increase the AVE and composite reliability above the threshold. The limit value of AVE is 0.50 , and the composite reliability is 0.70 . Another consideration in removing indicators is their impact on the content validity of the construct. Indicators with small loadings are sometimes maintained because they contribute to the validity of the constructed content.

From this analysis, the indicators KW2, KW5, KW8, KW9 for the Tourist Visit Rate constructs; indicators BP1, BP2, BP4 and BP7 for the Promotion mix constructs, as well as indicators SW2, SW4, and SW6 for the Tourism Activist Group constructs need to be dropped before the analysis can proceed. Several indicators that have a loading between 0.4 and 0.7 include KW10, KW11, BP3, BP5, BP6, BP8, BP9, SW1, SW5, and SW7, considering the $\mathrm{AVE}$ value and composite reliability after re-execution. If the value can meet the threshold limit, then the indicator is maintained. Otherwise, it must be dropped. Itconcludes that only the indicators ofKW1, KW3, KW4, KW6, KW7, KW11, BP3, BP5, BP6, BP8, BP9, SW1, SW3, SW5, and SW7 appliedfor the research.

\subsection{Direct EffectAnalysis}


The analysis of the influence of the exogenous latent variable of the Promotion Mix (BP) and the Tourism Activist Group (SW) on the endogenous latent variable of Tourist Visits Rate (KW) simultaneously provides the output of the analysis as shown in Table $\mathbf{1}$ as follow.

Table 1. Path Estimation of BP-KW, SW-KW Relationships

\begin{tabular}{|c|c|c|c|}
\hline \multicolumn{3}{|c|}{ Model fit indices and $P$ values } & General model elements \\
\hline \multicolumn{3}{|c|}{$\mathrm{APC}=0.174, \mathrm{P}<0.001$} & Algorithm used in the analysis: \\
\hline \multicolumn{3}{|c|}{$\mathrm{ARS}=0.092, \mathrm{P}=0.019$} & Warp3 PLS regression \\
\hline \multirow{2}{*}{\multicolumn{3}{|c|}{ AVIF $=1.338$, Good if $<5$}} & Resampling method used in the analysis: \\
\hline \multicolumn{2}{|c|}{ Model Estimation } & & Blindfolding \\
\hline & 3P-KW & SW-KW & Number of data resamples used: \\
\hline Path coefficient & 0.193 & 0.156 & Number of cases (rows) in model data: 99 \\
\hline$P$ values & 0.002 & 0.044 & Number of latent variables in the model: 3 \\
\hline Standard errors & 0.063 & 0.090 & Number of indicators used in the model: 16 \\
\hline Effect sizes $\left(\mathrm{R}^{2}\right)$ & 0.052 & 0.039 & Number of iterations to obtain estimates: 7 \\
\hline
\end{tabular}

The model has a goodness offit where the P values for APC and ARS are still $<0.050$. Likewise,AVIF is $1.338<5$, which means there is no multicollinearity problem betweenthe exogenous variables. The results of the estimated Path Coefficient of the BP-KW, SW-KW model are also shown in Table 1,indicating that the path coefficient for BP-KW is 0.193 with a P-value of $0.002(\mathrm{P}<0.01)$, a standard of errorof 0.063 , and an effect size $\left(\mathrm{R}^{2}\right)$ of 0.052 . Onthe path of SW-KW, we found acoefficientof 0.156anda P-value of 0.044, witha standard error of 0.090 and an effect size $\left(\mathrm{R}^{2}\right)$ of 0.039 . Itshows that the two exogenous latent variables, namely the Promotion Mix (BP) and the Tourism Activist Groups (SW), simultaneously have a significant positive effect on the endogenous latent variable of Tourist Visits Rate (KW).

\subsection{Indirect Effect Analysis}

The analysis of the indirect effect of the Exogenous Latent Variable of the Promotion Mix (BP) on the Endogenous Latent Variable of Tourist Visits (KW) with the Latent Variable the Tourism Activist Group (SW) as a mediating variable provides the output of the analysis as shown in Table 2. Itshows that the indirect effect model has significant goodness of fitfigure, where the P-value for APC and ARS is 0.001 . The AVIF value of $1.338<5$ also indicates that there is no multicollinearity problem between exogenous variables. The results of the estimation of the Path Coefficient of the SW mediation model on the influence of BP$\mathrm{KW}$ are as shown in Fig. 3.

Table 2. Path Estimation of SW Mediation on BP-KW

\begin{tabular}{|c|c|c|c|c|}
\hline \multicolumn{4}{|c|}{ Model fit indices and P values } & General model elements \\
\hline \multicolumn{4}{|c|}{$\mathrm{APC}=0.318, \mathrm{P}<0.001$} & Algorithm used in the analysis: \\
\hline \multicolumn{4}{|c|}{$\mathrm{ARS}=0.229, \mathrm{P}=0.001$} & Warp3 PLS regression \\
\hline \multicolumn{4}{|c|}{$\mathrm{AVIF}=1.338$, Good if $<5$} & Resampling method used in the analysis: \\
\hline \multicolumn{4}{|c|}{ Model Estimation } & Blindfolding \\
\hline & BP-KW & SW-KW & BP-SW & Number of data resamples used: \\
\hline Path coefficient & 0.193 & 0.156 & 0.605 & Number of cases (rows) in model data: 99 \\
\hline $\mathrm{P}$ values & 0.002 & 0.044 & $<0.001$ & Number of latent variables in the model: 3 \\
\hline Standard errors & 0.063 & 0.090 & 0.095 & Number of indicators used in the model: 16 \\
\hline Effect sizes $\left(\mathrm{R}^{2}\right)$ & 0.052 & 0.039 & 0.366 & Number of iterations to obtain estimates: 7 \\
\hline
\end{tabular}




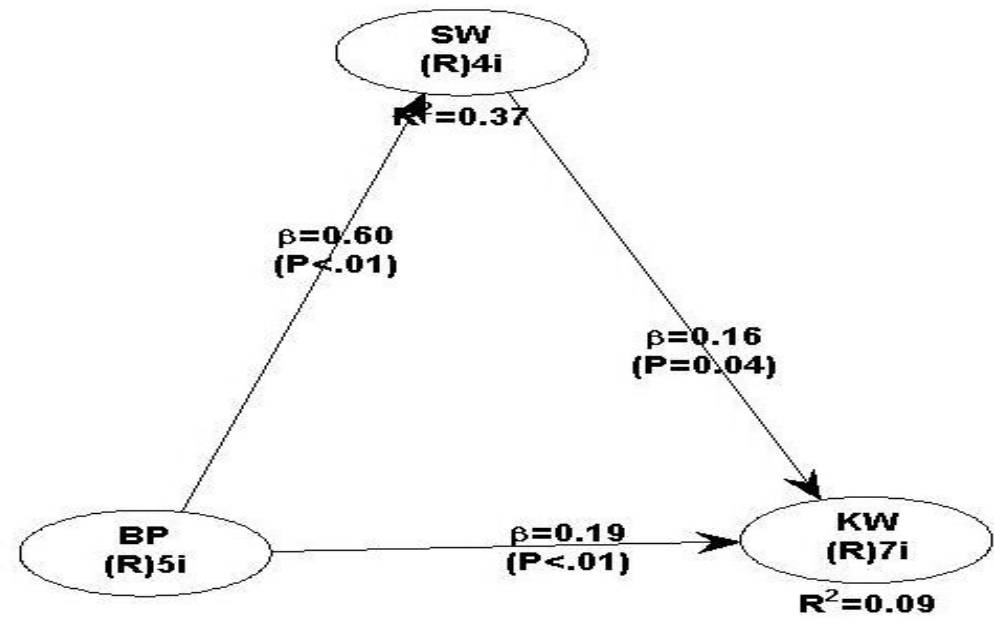

Fig. 3. Path Estimation of SW Mediation on BP-KW

Fig. 3 also shows the path coefficient values of BP-KW and BP-SW of 0.193 and 0.156 , respectively, with $P$ values of 0.002 and 0.044 , a significance level of $95 \%$. The value of the Total Effect size is 0.090 and means that BP and SW affect changes in KW only by 9\%.The remaining $91 \%$ is influenced by other variables outside of BP and SW. Itmeans that simultaneously the Promotion Mix (BP) and the Tourism Activist Group (SW) have a significant, although the small positive effect on the Tourist Visit Rate (KW)

The mediation-effect test (Baron \& Kenny,1986 in Kristaung \&Fiorini, 2019) may be followed ifthe effect of the exogenous variable (X) on the endogenous variable (Y) is significant. (If this does not occur or is not significant, the mediation effect test cannot be continued.)However, the advantage of WarpPLS is in providing the output of the calculation of the indirect effect coefficient and its significance using the Sobel formula (Ghozali \& Latan, 2015). Table 3 shows the results of the WarpPLS analysis on the mediating effect of the latent variable $\mathrm{SW}$ on the BP-KW relationship.

The estimation result of the direct model shows that the direct effect coefficient of BP on $\mathrm{KW}$ is 0.271 and is significant at a P-value $<0.001$. Meanwhile, the estimation result of BP's indirect effect on KW decreased to 0.193 but remained significant at a P-value $=0.002$. Itshowspartial mediation, or in other words, the role of tourism group awareness (SW) partially mediates the effect of the Promotion Mix(BP) on the Tourist Visit Rate (KW). However, there may be other mediating factors (Baron and Kenny 1986).

The test results show support for the hypothesis that the Tourism Activist Group (SW) has an indirect effect on Tourist Visit Rate $(\mathrm{KW})$, acting as a partial mediating of the relationship between Promotion Mix (BP) and Tourist Visit Rate (KW). Table 3is an advantage of WarpPLS and shows the indirect effects of coefficients and their significance.The estimation results show that the influence of BP on performance indirectly and through SW is 0.094 . The indirect coefficient of BP on KW is significant, with a $\mathrm{P}$-value of 0.040. To calculate the significance level manually, we need the Sobel formula, which is quite complicated. In addition, the formula is limited to two paths only. The significant 
indirect effect of BP on KW shows $\mathrm{SW}$ as a mediating variable, where $\mathrm{SW}$ is considered a partial mediation variableaccording to the results of the two-step approach above.

Table 3. Indirect Effects and Total Effects Estimation

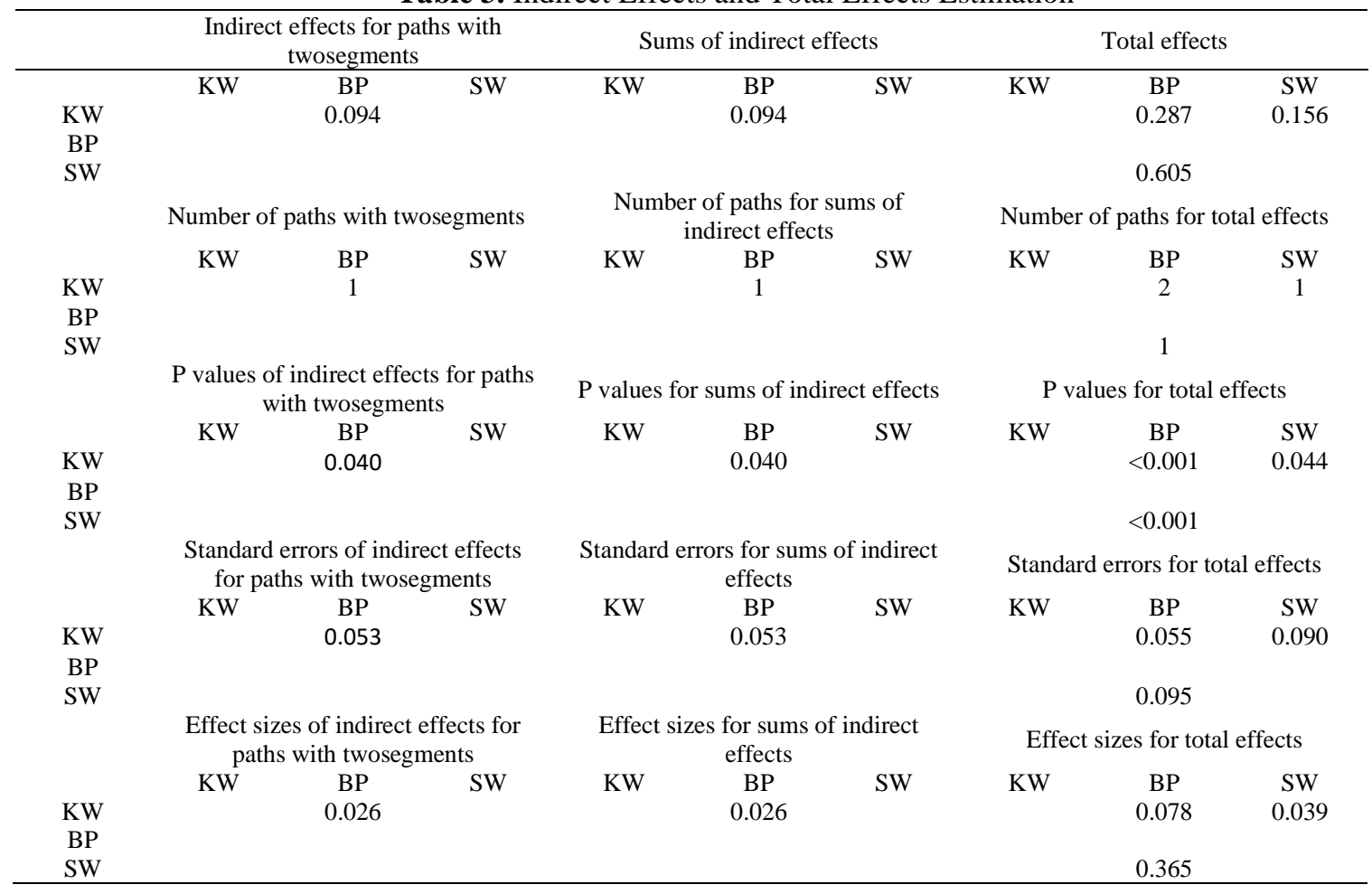

\subsection{Output Latent Variable Coefficients}

The output of the Latent Variable Coefficient analysis is shown in Table 4. The figures in the table show the coefficient of determination, instrument reliability, discriminant validity, full collinearity test, and predictive validity.

Tabel 4. Latent Variable Coefficient

\begin{tabular}{lccc}
\hline & KW & BP & SW \\
\hline R-squared coefficients & 0.092 & & 0.366 \\
Q-squared coefficients & 0.103 & & 0.383 \\
Composite reliability coefficients & 0.903 & 0.803 & 0.767 \\
Cronbach's alpha coefficients & 0.873 & 0.694 & 0.595 \\
Average variances extracted & 0.571 & 0.451 & 0.453 \\
Full collinearity VIFs & 1.080 & 1.571 & 1.572 \\
\hline
\end{tabular}

\subsubsection{Coefficient of determination $\left(R^{2}\right)$}

The coefficient of determination uses an $\mathrm{R}^{2}$ value which indicates what percentage of the endogenous construct/criteria variance can be explained by the construct that is hypothesized to affect it (exogenous/predictor). The higher $\mathrm{R}^{2}$ indicates a good model. R- 
squared only exists for endogenous constructs. In this study, the $\mathrm{R}^{2}$ construct of the Tourist Visit Rate is 0.092 , indicating that the variance of the Tourist Visit Rate can be explained by $9.2 \%$ by the variance of BP and SW.

\subsubsection{Q-squared $\left(Q^{2}\right)$}

Q-squared, also known as the Stoner-Geisser coefficient, is a non-parametric measure obtained through a blindfolding algorithm. $\mathrm{Q}^{2}$ is used to assess the predictive validity or relevance of a set of predictor latent variables on the criterion variable. $\mathrm{Q}^{2}$ is analogous to $\mathrm{R}$ squared but can only be obtained through resampling. $\mathrm{Q}^{2}$ can be negative while the value of $\mathrm{R}^{2}$ is always positive. Models with predictive validity must have a $\mathrm{Q}^{2}$ value greater than zero. The estimation results of this research model show good predictive validity (i.e.0.103 and 0.383 ) sincethe figures are above zero.

\subsubsection{Composite reliability and Cronbach's alpha (Reliability Instrument)}

The reliability of the research instrument was measured by composite reliability and Cronbach's alpha. Both must be valued above 0.70 as a condition of reliability (Fornell and Lacker, 1981; Nunnaly, 1978). The output of this study shows that the instrument's reliability has been met because the composite reliability value is above 0.70 . Likewise, for Cronbach's alpha, the KW variable has a value above 0.7 , but for SW, it has a Cronbach's alpha value of 0.595 , slightly below 0.7 ,

\subsubsection{Average variance extracted}

The average variance extracted(AVE) is also used to evaluate convergent validity. The criteria must be above 0.50 (Fornell and Lacker, 1981). In this case, the research output shows that the AVE values for the KW, BP and SW are 0.571, 0.451, and 0.453, respectively. Thus, the instrument variable $\mathrm{KW}$ is valid, and the $\mathrm{BP}$ and $\mathrm{SW}$ variables have a value slightly below 0.5 .

\subsubsection{Full collinearity VIF}

Full collinearity VIF is the result of full collinearity testing. This test includes vertical and lateral multicollinearity. This output is also an advantage of WarPLS 3.0 that does not exist in other software. Full collinearity test results are presented for each latent variable. The collinearity that we know is called vertical or classical. It also shows the collinearity between predictor variables in the same block. Here there is a new concept, namely the collinearity between the predictor latent variable and the criterion. Lateral collinearity is often ignored, even though it can lead to biased research results. Lateral collinearity is also used to test common method bias. The criteria for the full collinearity test is that the value must be lower than 3.3 (Kock, 2013). In this study, the output shows the value of full collinearity VIF is less than 3.3. The model is free from problems of vertical, lateral collinearity, and common method bias. 


\section{Conclusion}

Based on the results of the analysis, the following conclusions can be drawnaboutBenan Village, Lingga Regency, Riau Islands Province: a) Promotion Mix has a significant positive effect on the Tourist Visits Rate; b) The Tourism Activist Group has a significant positive effect on the Tourist Visits Rate; c) Promotion mix and Tourism Activist Group simultaneously have a positive and significant effect on the Tourist Visits Rate; and d) The Tourism Activist Group merely acts as a Partial Mediation Variable of the indirect relationship between the Promotion Mix and the Tourist Visits Rate. Thus, it can be concluded that the Benan Island Tourism Promotion carried out by the local government has not optimally used the Promotion Mixto increase the number of touristsvisitingBenan Island.Similarly, the Tourism Activist Group also has not been optimally utilizedto increase the tourist visit rate.

\section{References}

[1] Ghozali, I., \& Latan, H. (2015). Partial Least Squares: Konsep, Teknik dan Aplikasi Menggunakan Program SmartPLS 3.0 untuk Penelitian Empiris (2nd ed.). Badan Penerbit Universitas Diponegoro.

[2] Handayani, E., \& Dedi, M. (2017). Pengaruh Promosi Wisata Bahari Dan Kualitas Pelayanan Terhadap Peningkatan Jumlah Kunjungan Wisatawan Di Pelabuhan Muncar Banyuwangi. Jurnal Wira Ekonomi Mikroskil, 7(2), 151-159.

[3] Kock, N. (2012). WarpPLS 3.0 user manual. Laredo, Texas: ScriptWarp Systems. Retrieved April. http://www.scriptwarp.com/warppls/UserManual_WarpPLS_V2.pd

[4] Kotler, P., \& Amstorong, G. (2016). Prinsiples of Marketing (sixteenth). Pearson.

[5] Kristaung, R., \& Riorini, V. (2019). Mediation-Moderation Modeling in Marketing Research Literature Review and Classification. International Journal of Innovation, Creativity and Change. Www.Ijicc.Net, 7(8). www.ijicc.net

[6] Latan, H., \& Ghozali, I. (2012). Partial Least Square: Konsep, Metode dan Aplikasi Menggunakan Program WarpPLS 2.0 untuk Penelitian Empiris. Badan Penerbit Universitas Diponegoro.

[7] Mursid, M. (2013). Manajemen pemasaran (Cet. 7). Bumi Aksara.

[8] Preacher, K. J., \& Hayes, A. F. (2004). SPSS and SAS procedures for estimating indirect effects in simple mediation models. Behavior Research Methods, Instruments, \& Computers, 36(4), 717-731. https://doi.org/10.3758/BF03206553

[9] Rispawati, D. (2019). Promotion Mix Pariwisata dalam Rangka Meningkatkan Jumlah Kunjungan Wisatawan ke Provinsi Nusa Tenggara Barat. Media Bina Ilmiah, 13(9). https://doi.org/10.33758/mbi.v13i9.244

[10] Setiawan, N. A., \& Farid, H. (2014). Strategi Promosi dalam Pengembangan Pariwisata Lokal di Desa Wisata Jelekong. Trikonomika, 13(2), 184. https://doi.org/10.23969/trikonomika.v13i2.613

[11] Sholihin, M., \& Ratmono, D. (2013). Analisis SEM-PLS dengan WarpPLS 3.0 untuk Hubungan Nonlinier dalam Penelitian Sosial dan Bisnis (1st ed.). Penerbit ANDI.

[12] Sujarweni, V. W. (2015). Metodologi Penelitian Bisnis dan Eekonomi. Pustaka baru. 